\title{
SOME SHARP INEQUALITIES FOR MULTIDIMENSIONAL INTEGRAL OPERATORS WITH HOMOGENEOUS KERNEL: AN OVERVIEW AND NEW RESULTS
}

\author{
D. LukKassen, L.-E. Persson, S. G. SAmko And P. WALl
}

\begin{abstract}
One goal of this paper is to point out the fact that a big number of inequalities proved from time to time in journal publications, both one-dimensional and multi-dimensional, are particular cases of some general results for integral operators with homogeneous kernels, including in particular, the statements on sharp constants.

Some new multidimensional Hardy-Hilbert type inequalities are derived. Moreover, a new multidimensional Pólya-Knopp inequality is proved and some examples of applications are derived from this result. The constants in all inequalities are sharp.
\end{abstract}

Mathematics subject classification (2010): 26D10, 26D15.

Keywords and phrases: Multidimensional inequalities, Hardy-Hilbert type inequalities, Pólya-Knopp type inequalities, sharp constants.

\section{REFERENCES}

[1] M. Christ and L. Grafakos, Best constant for two non-convolution inequalities, Proc. Amer. Math. Soc., 123 (6): 1687-1693.

[2] E. B. Davies AND A. M. HinZ, Explicit constants for Rellich inequalities in $L^{p}(\Omega)$, Math. Z., 227 (3): 511-523, 1998.

[3] P. DrábeK, H. P. Heinig And A. Kufner, Higher-dimensional Hardy inequality, In General inequalities, 7 (Oberwolfach, 1995), volume 123 of Internat. Ser. Numer. Math., pages 3-16. Birkhäuser, Basel, 1997.

[4] S. Eilertsen, On weighted fractional integral inequalities, J. Funct. Anal., 185 (1): 342-366, 2001.

[5] H. G. HARDY, Notes on some points in the integral calculus, LX. An inequality between integrals, Messenger of Math., 54: 150-156, 1925.

[6] G. H. HARDY, it Notes on some points in the integral calculus, LXIV. Futher inequalities between integrals, Messenger of Math., 57: 12-16, 1928.

[7] G. Hardy, J. Littlewood and G. Pólya, Inequalities, Cambridge University Press, Cambridge, 1934.

[8] D. HilberT, Grundzüge ciner allgemeinen Theory der Linearen Integralgleichungen, Göttinger Nachr: 157-227, 1906.

[9] D. HilberT, Grundzüge ciner allgemeiner Theory der Linearen Integralgleichungen, Teubner, Leipzig, 1912.

[10] N. K. KARAPETIANTS, On necessary boundedness conditions of operators with a nonnegative quasihomogenous kernel, (Russian), Mat. Zametki, 30 (5): 787-794, 1981.

[11] N. K. Karapetiants AND S. G. SAmKo, it Multidimensional integral operators with homogeneous kernels, Fract. Calc. Appl. Anal., 2 (1): 67-96, 1999.

[12] N. K. Karapetiants AND S. G. SAmKo, Equations with Involutive Operators, Birkhäuser, Boston, 2001.

[13] K. KNOPP, Über reihen mit positivern gliedern, J. London Math. Soc., 3: 205-211, 1928.

[14] V. KokilashVili, A. Meskhi And L.-E. Persson, Weighted norm inequalities for integral transforms with product kernels, Nova Science Publishers, New York, 2010. 
[15] M. KRnić, J. PeČARIĆ, I. Perić And P. Vukovič, Recent Advances in Hilbert-type Inequalities, Element, Zagreb, 2012.

[16] A. Kufner, L. Maligranda And L.-E. Persson, The Hardy Inequality. About its History and Some Related Results, Vydavatelsky Servis Publishing House, Pilsen, 2007.

[17] A. Kufner, L. Maligranda And L.-E. Persson, The prehistory of the Hardy inequality, Amer. Math. Monthly, 113: 715-732, 2007.

[18] A. Kufner And L.-E. Persson, Weighted inequalities of Hardy type, World Scientific Publishing Co. Inc., River Edge, NJ, 2003.

[19] L. G. Mikhailov, On some multi-dimensional integral equations with homogeneous kernels, (Russian), Dokl. Akad. Nauk SSSR, 176 (2): 263-265, 1967.

[20] I. PERIĆ AND P. VUKOvić, Multiple Hilbert's type inequalities with homogeneous kernels, Banach J. Math. Anal., 5: 33-43, 2011.

[21] S. Samko, Proof of the Babenko-Stein theorem, (Russian), Izv. Vysch, Uchebn. Zaved., Matematika., (5): 47-51, 1975.

[22] S. S Aмко, Best constant in the weighted Hardy inequality: the spatial and spherical version, Fract. Calc. Appl. Anal., 8 (1): 39-52, 2005.

[23] S. G. SAmko, A. A. Kilbas And O. I. Marichev, Fractional Integrals and Derivatives. Theory and Applications, London - New-York: Gordon \& Breach. Sci. Publ., (Russian edition - Fractional Integrals and Derivatives and some of their Applications, Minsk: Nauka i Tekhnika, 1987.), 1993.

[24] E. M. STEIn AND G. WeIss, Fractional integrals on $n$-dimensional Euclidean space, J. Math. Mech., 7 (4): 503-514, 1958.

[25] E. M. Stein And G. Weiss, Introduction to Fourier Analysis on Euclidean Space, Princeton University Press, 1971. (Russian edition), Moscow: Mir, 1974.

[26] H. WEYL, Singulare Integralgleichungen mit besonderer Berücksichtigung des Fourierscen Integraltheorems, $\mathrm{PhD}$ dissertation. Göttingen, 1908.

[27] D. YAfAEv, Sharp constants in the Hardy-Rellich inequalities, J. Funct. Anal., 168 (1): 121-144, 1999.

[28] Hong Yong, A multiple Hardy-Hilbert integral inequality with the best constant factor, J. Inequal. Pure Appl. Math., 7 (4), 2006. 